\title{
Microstructure Analysis and Properties of Anti-Reflection Thin Films for Spherical Silicon Solar Cells
}

\author{
Masato Kanayama $^{1}$, Takeo Oku ${ }^{1 *}$, Tsuyoshi Akiyama ${ }^{1}$, Youichi Kanamori ${ }^{2}$, \\ Satoshi Seo ${ }^{2}$, Jun Takami ${ }^{2}$, Yoshimasa Ohnishi ${ }^{2}$, Yoshikazu Ohtani ${ }^{2}$, Mikio Murozono ${ }^{2}$ \\ ${ }^{1}$ Department of Materials Science, The University of Shiga Prefecture, Shiga, Japan \\ ${ }^{2}$ Clean Venture 21 Co. Ltd., Kyoto, Japan \\ Email: *oku@mat.usp.ac.jp
}

Received February 13, 2013; revised March 10, 2013; accepted March 27, 2013

Copyright (C) 2013 Masato Kanayama et al. This is an open access article distributed under the Creative Commons Attribution License, which permits unrestricted use, distribution, and reproduction in any medium, provided the original work is properly cited.

\begin{abstract}
Structure and properties of anti-reflection thin films of spherical silicon solar cells were investigated and discussed. Conversion efficiencies of spherical Si solar cells coated with F-doped $\mathrm{SnO}_{2}$ anti-reflection films were improved by annealing. Optical absorption and fluorescence of the solar cells increased after annealing. Lattice constants of F-doped $\mathrm{SnO}_{2}$ anti-reflection layers, which were investigated by X-ray diffraction, decreased after annealing. A mechanism of atomic diffusion of $\mathrm{F}$ in $\mathrm{SnO}_{2}$ was discussed. The present work indicated a guideline for spherical silicon solar cells with higher efficiencies.
\end{abstract}

Keywords: Solar Cells; Spherical Silicon; Anti-Reflection Film; FTO; $\mathrm{SnO}_{2}$

\section{Introduction}

Solar cells are expected to be clean energy devices instead of fossil fuels. They are clean energy devices which discharge no greenhouse gas. However, reduction of the cost of solar cells is an important issue. Spherical silicon (Si) solar cells [1-3] are the technology that can reduce the consumption of Si compared with conventional crystal Si solar cells [4-6]. Flexible solar cells are also manufactured by silicon spheres with a diameter of $\sim 1 \mathrm{~mm}$ with p-n junction [7]. To Improve the efficiencies of the $\mathrm{Si}$ solar cells [8], formation of a texture structure on $\mathrm{Si}$ surface [9-11], optimization of structures of reflectors [12-14], reduction in resistance and high transmission of anti-reflection films [15-17] are also needed.

The purpose of the present work is to investigate spherical Si solar cells with anti-reflection (AR) $\mathrm{SnO}_{2}: \mathrm{F}$ thin films.

\section{Experimental}

The spherical silicon used in the present experiment was supplied by Clean Venture 21 Co., Ltd. [18,19]. The surface is covered with anti-reflection films of $\mathrm{SnO}_{2}: \mathrm{F}$. The $\mathrm{SnO}_{2}: \mathrm{F}$ anti-reflection films were prepared by spraying hydrolyzed $\mathrm{SnF}_{4}$, and annealed at $650^{\circ} \mathrm{C}$ for $4 \mathrm{~h}$ to form the $\mathrm{SnO}_{2}: \mathrm{F}$ crystal structure [20-23]. Figure 1 shows a schematic illustration of spherical Si solar cell. Reflectors gather lights to improve conversion efficiency. Optical absorption of the solar cells was measured by photo spectroscopy (Jasco V-670). Fluorescence spectra of the samples were measured by fluorescence spectrophotometer (Hitachi F-4500), and excitation wavelength was $250 \mathrm{~nm}$. The microstructures of $\mathrm{SnO}_{2}: \mathrm{F}$ films were investigated by X-ray diffraction (XRD, Philips X'PertMPD System). Thermodynamical calculation of reactions of $\mathrm{SnO}_{2}$ was performed by HSC Chemistry 5 .

\section{Results and Discussions}

Figure 2(a) shows measured optical absorption of spherical Si before and after annealing. The spherical $\mathrm{Si}$ absorbs the light in the range of 300 to $1200 \mathrm{~nm}$. The optical absorption of the spherical Si increased after annealing at $650^{\circ} \mathrm{C}$. Figure 2(b) shows optical absorption spectra of $\mathrm{SnO}_{2}: \mathrm{F}$, which was an enlarged spectrum of Figure 2(a). Since the absorption range was shifted to lower energy, a structural change would occur after annealing. The refractive index of anti-reflection $\mathrm{SnO}_{2}: \mathrm{F}$ films changed from 1.8 to 1.9 after annealing. Refractive indices of the substrate and anti-reflection films would influence reflectance and optical absorption. Since refractive indices are different for wavelengths of light, the effect of the reflectance reduction depends on the wave- 




Figure 1. Schematic illustration of spherical Si solar cell.

(a)

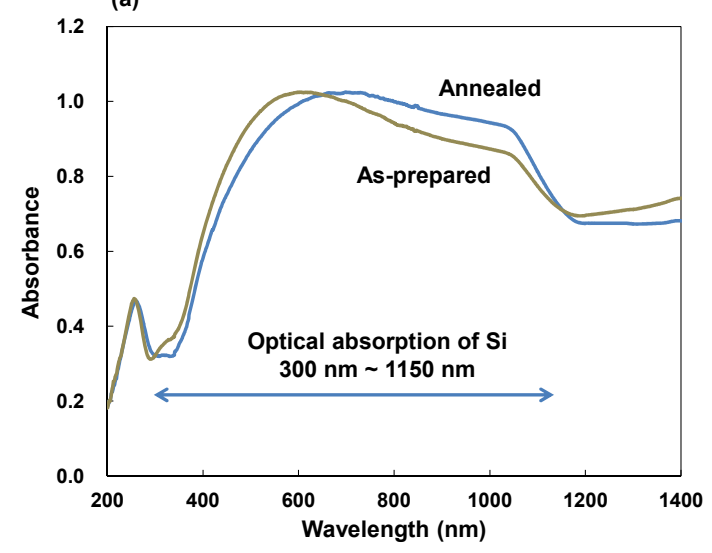

(b)

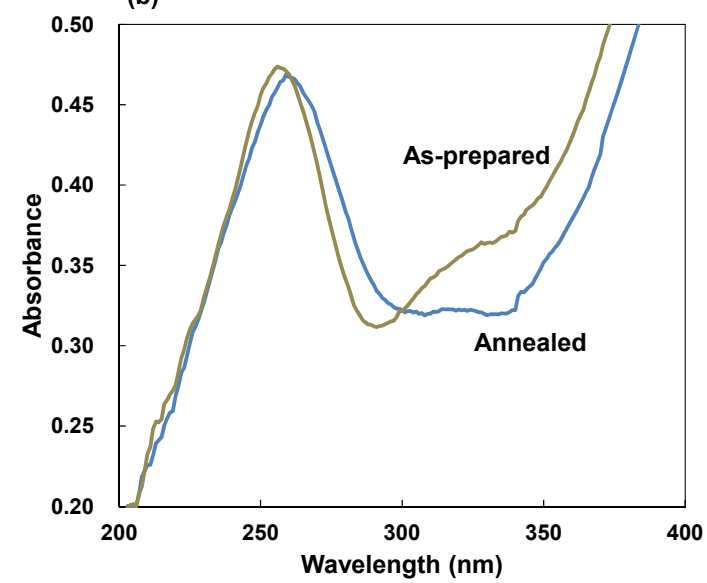

Figure 2. Optical absorption of (a) spherical Si with AR films. (b) Enlarged spectra of (a) for $\mathrm{SnO}_{2}: \mathrm{F}$ spectra.

length.

Figure 3 shows fluorescence spectra of spherical $\mathrm{Si}$ before and after annealing. The energy gap of $\mathrm{SnO}_{2}$ is 3.8 $\mathrm{eV}$, and fluorescence peaks of $\mathrm{SnO}_{2}$ are observed at $\sim 350$ $\mathrm{nm}$. Fluorescence spectra due to impurities in Si might also be contained in the spectra [24]. The fluorescence of $\mathrm{SnO}_{2}$ increased after annealing. Therefore, the crystallinity would be improved by the annealing.

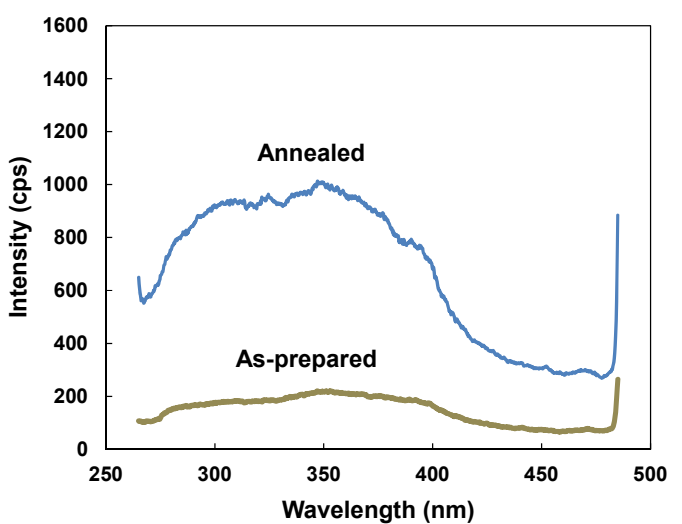

Figure 3. Fluorescence spectra of spherical Si with AR films.

Figure 4 show measured X-ray diffraction patterns of spherical silicon before and after annealing. Miller indices of $\mathrm{Si}$ and $\mathrm{SnO}_{2}$ are indicated in Figure 4(a) [25,26]. Figure 4(b) shows that the 110 peak of $\mathrm{SnO}_{2}$ shifted to higher diffraction angle after annealing.

The $\mathrm{SnO}_{2}$ grain sizes calculated from the XRD measurements are summarized in Table 1 and Figure 5. The grain sizes $D$ were calculated using Scherrer's formula.

$$
D=0.9 \lambda / B \cos \theta
$$

where $\lambda, B$, and $\theta$ represent the wavelength of X-ray source, the full width at half maximum, and the Bragg angle, respectively.

Lattice constants of a-axis and c-axis for $\mathrm{SnO}_{2}$ calculated from the XRD measurements are shown in Figure 6. The measured grain sizes and lattice constants of $\mathrm{SnO}_{2}$ before and after annealing are summarized in Table 1.

$\mathrm{SnO}_{2}$ crystals have high electrical resistance, and doped $\mathrm{F}$ and oxygen vacancies are electrical carriers for $\mathrm{SnO}_{2}: \mathrm{F}$ [27-30]. To consider the change of the oxygen vacancy by annealing, thermodynamical calculation was carried out as shown in Figure 7. Gibbs free energy change $(\Delta \mathrm{G})$ for $\mathrm{SnO}_{2}$ oxidation is negative at $650^{\circ} \mathrm{C}$ in the atmosphere, which suggests oxygen vacancies in $\mathrm{SnO}_{2}$ decrease after annealing, and $\mathrm{F}$ atoms would occupy oxygen sites.

If oxygen vacancy decreases, an increase of lattice constants may be expected, but they decreased as indicated in Table 1. Therefore, it is considered that reduction of lattice constants occurred since interstitial $\mathrm{F}$ atoms were removed or substituted for the oxygen sites. Schematic illustration of structural change of $\mathrm{SnO}_{2}: \mathrm{F}$ by annealing is shown in Figure 8.

The performances of the present solar cells are summarized in Table 2. The performance of the spherical Si solar cells was improved after annealing. If some atoms exist at interstitial sites, electronic resistance increases. Although $\mathrm{SnO}_{2}$ has no optical absorption on the absorption wavelength of $\mathrm{Si}$, the contained impurities in $\mathrm{SnO}_{2}$ 

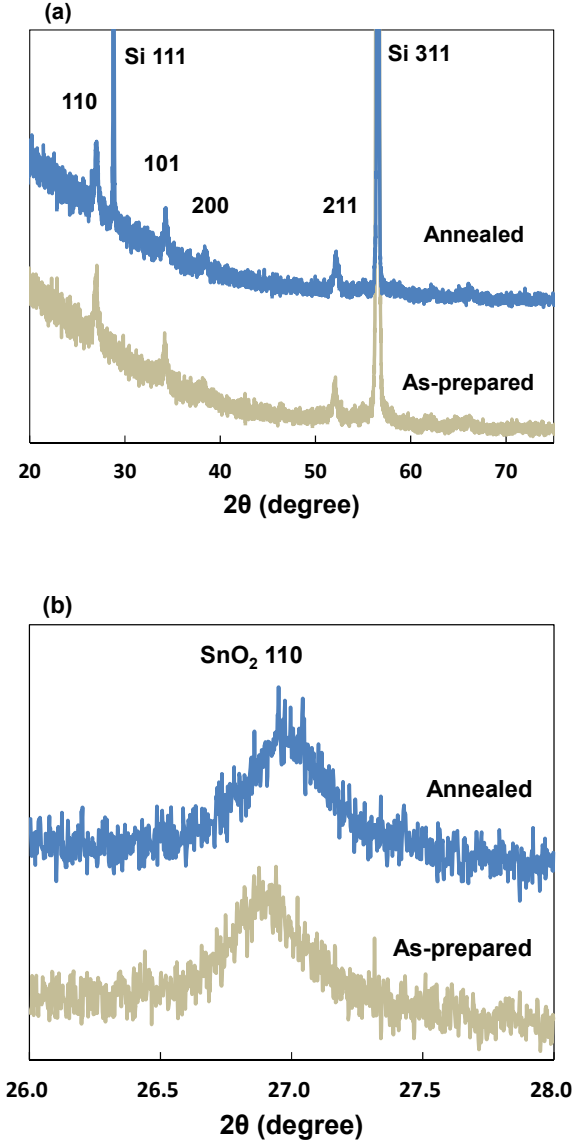

Figure 4. (a) XRD patterns of spherical Si with AR films. (b) Enlarged patterns of (a) for $\mathrm{SnO}_{2}: \mathrm{F} 110$.

Table 1. Grain sizes and lattice constants of $\mathrm{SnO}_{2}: \mathrm{F}$.

\begin{tabular}{cclc}
\hline \multirow{2}{*}{ Samples } & \multirow{2}{*}{ Grain size $(\mathrm{nm})$} & \multicolumn{2}{l}{ Lattice constant $(\mathrm{nm})$} \\
\cline { 3 - 4 } & & a-axis & c-axis \\
\hline As-prepared & 41.0 & 0.4713 & 0.3182 \\
Annealed & 56.4 & 0.4695 & 0.3170 \\
$\mathrm{SnO}_{2}$ & - & 0.4737 & 0.3185 \\
\hline
\end{tabular}



Figure 5. Grain sizes of $\mathrm{SnO}_{2}:$ F.

would be a cause of light dispersion and absorption [31]. Reduction of interstitial atoms caused decreases electronic resistance, and increasing the optical absorption of $\mathrm{Si}$, and improve the conversion efficiency of the solar
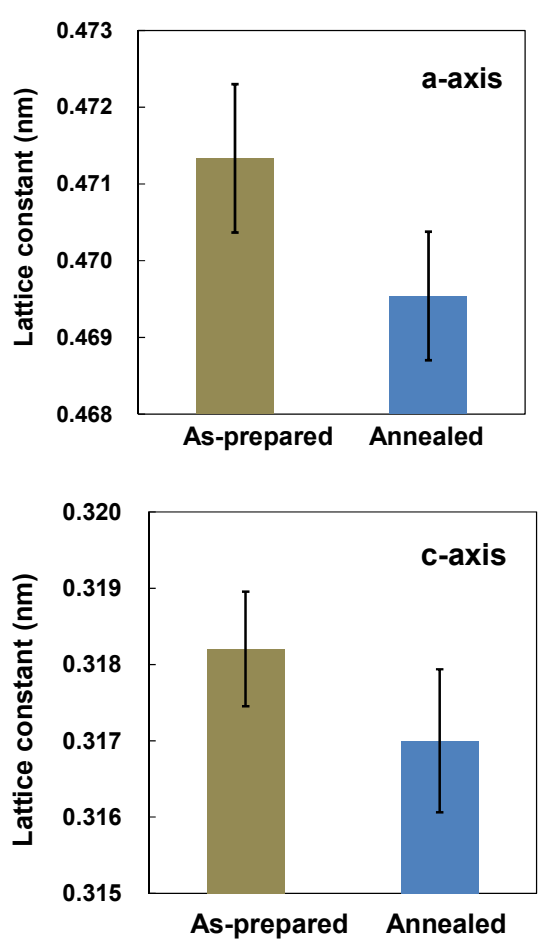

Figure 6. Lattice constants of $\mathrm{SnO}_{2}: \mathrm{F}$.

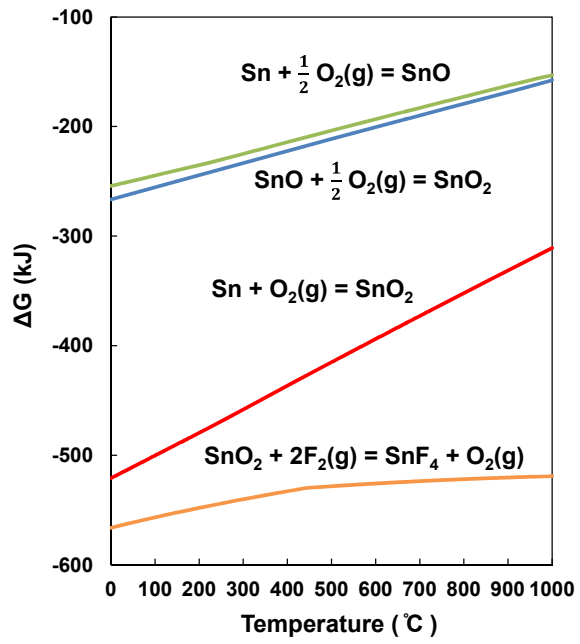

Figure 7. Thermodynamical calculation of $\mathrm{SnO}_{2}$.

cells. By F-doping to anti-reflection films, carriers increase and resistance decreases. Simultaneously, transparency decreases since carrier elements absorb light and cause light dispersion. Reduction of the interstitial $\mathrm{F}$ atoms also caused increase of the optical absorption of Si. Reduction of the lattice constants would be due to the decrease of $\mathrm{F}$ which exists at interstitial sites in $\mathrm{SnO}_{2}$ cause electronic resistance. The present results indicated that the microstructures and properties of AR films depended on the annealing process, and that optimization of the formation process of AR films are mandatory for further improvement of the performance. 
(a)

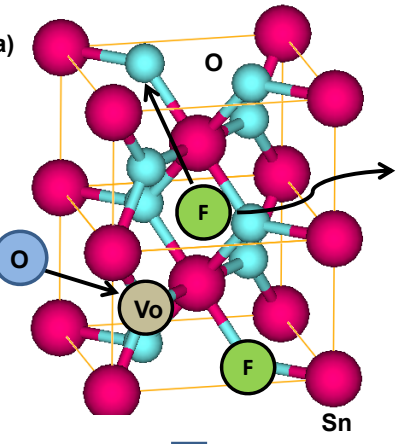

(b)



Figure 8. Schematic illustration of atomic transfer (a) during and (b) after annealing.

Table 2. Parameters of spherical silicon solar cells.

\begin{tabular}{cccccc}
\hline Samples & $J_{s c}\left(\mathrm{~mA} \cdot \mathrm{cm}^{-2}\right)$ & $V_{o c}(\mathrm{~V})$ & $\mathrm{FF}$ & $\eta(\%)$ & $R s(\Omega)$ \\
\hline As-prepared & 24.9 & 0.511 & 0.542 & 6.90 & 89.0 \\
Annealed & 26.3 & 0.593 & 0.717 & 11.2 & 59.3 \\
\hline
\end{tabular}

\section{Conclusion}

The efficiency of the spherical Si solar cells with AR F-doped $\mathrm{SnO}_{2}$ films was improved after annealing at $650^{\circ} \mathrm{C}$ for $4 \mathrm{~h}$. After annealing, the optical absorption of spherical Si increased and resistance decreased. Since the lattice constants of $\mathrm{SnO}_{2}: \mathrm{F}$ decreased after annealing, the interstitial $\mathrm{F}$ atoms would be reduced. The reduction of resistance and the improvement of optical absorption would be due to the reduction of the interstitial $\mathrm{F}$ atoms, and it is possible to adjust $\mathrm{F}$ doping for the $\mathrm{SnO}_{2}$ by annealing.

\section{Acknowledgements}

The authors would like to acknowledge H. Miyamura, Y. Ono, Y. Akashi and T. Usuki for experimental help and useful discussion.

\section{REFERENCES}

[1] T. Maruyama and H. Minami, "Light Trapping in Spherical Silicon Solar Cell Module," Solar Energy Materials and Solar Cells, Vol. 79, No. 2, 2003, pp. 113-124. doi:10.1016/S0927-0248(02)00375-6
[2] Z. Liu, A. Masuda and M. Kondo, "Investigation on the Crystal Growth Process of Spherical Si Single Crystals by Melting," Journal of Crystal Growth, Vol. 311, No. 16, 2009, pp. 4116-4122. doi:10.1016/j.jcrysgro.2009.06.042

[3] M. Gharghi and S. Sivoththaman, "Growth and Structural Characterization of Spherical Silicon Crystals Grown from Polysilicon," Journal of Electronic Materials, Vol. 37, No. 11, 2008, pp. 1657-1664. doi:10.1007/s11664-008-0547-8

[4] C. Okamoto, T. Minemoto, M. Murozono1, H. Takakura and Y. Hamakawa, "Defect Evaluation of Spherical Silicon Solar Cells Fabricated by Dropping Method," Japanese Journal of Applied Physics, Vol. 44, No. 11, 2005, pp. 7805-7808. doi:10.1143/JJAP.44.7805

[5] Z. Liu, T. Nagai, A. Masuda and M. Kondo, "Seeding Method with Silicon Powder for the Formation of Silicon Spheres in the drop Method," Journal of Applied Physics, Vol. 101, No. 9, 2007, Article ID: 093505. doi:10.1063/1.2718872

[6] T. Minemoto and H. Takakura, "Fabrication of Spherical Silicon Crystals by Dropping Method and Their Application to Solar Cells," Japanese Journal of Applied Physics, Vol. 46, No. 7A, 2007, pp. 4016-4020. doi:10.1143/JJAP.46.4016

[7] M. Gharghi, "Three-Dimensional Modeling and Simulation of p-n Junction Spherical Silicon Solar Cells," IEEE Transactions on Electron Devices, Vol. 53, No. 6, 2006, pp. 1355-1363. doi:10.1109/TED.2006.873843

[8] Z. Liu, A. Masuda and M. Kondo, "Investigating Minority-Carrier Lifetime in Small Spherical Si Using Microwave Photoconductance Decay," Journal of Applied Physics, Vol. 103, No. 10, 2008, Article ID: 104909. doi:10.1063/1.2936979

[9] X. S. Hu, Y. J. Zhang and H. W. Wang, "The Effect of Texture Unit Shape on Silicon Surface on the Absorption Properties," Solar Energy Materials and Solar Cells, Vol. 94, No. 2, 2010, pp. 258-262. doi:10.1016/j.solmat.2009.09.011

[10] J. Yoo, G. Yu and L. J. Yi, "Large-Area Multicrystalline Silicon Solar Cell Fabrication Using Reactive Ion Etching (RIE)," Solar Energy Materials and Solar Cells, Vol. 95, No. 1, 2011, pp. 2-6. doi:10.1016/j.solmat.2010.03.029

[11] S. Hayashi, T. Minemoto, H. Takakura and Y. Hamakawa, "Influence of Texture Feature Size on Spherical Silicon Solar Cells," Rare Metals, Vol. 25, No. 6, 2006, pp. 115120. doi:10.1016/S1001-0521(07)60056-4

[12] T. Minemoto, M. Murozono, Y. Yamaguchi, H. Takakura and Y. Hamakawa, "Design Strategy and Development of Spherical Silicon," Solar Energy Materials \& Solar Cells, Vol. 90, No. 18-19, 2006, pp. 3009-3013. doi:10.1016/j.solmat.2006.06.016

[13] Z. Liu, A. Masuda and T. Nagai, "A Concentrator Module of Spherical Si Solar Cell," Solar Energy Materials and Solar Cells, Vol. 91, No. 19, 2007, pp. 1805-1810. doi:10.1016/j.solmat.2007.06.008

[14] T. Minemoto, M. Murozono, Y. Yamaguchi, H. Takakura and Y. Hamakawa, "Design Strategy and Development of Spherical Silicon Solar Cell with Semi-Concentration Reflector System," Solar Energy Materials and Solar Cells, 
Vol. 90, No. 18-19, 2006, pp. 3009-3013. doi:10.1016/j.solmat.2006.06.016

[15] T. Mizuta, T. Ikuta, T. Minemoto, H. Takakura, Y. Hamakawa and T. Numai, "An Optimum Design of Antireflection Coating for Spherical Silicon Solar Cells," Solar Energy Materials and Solar Cells, Vol. 90, No. 1, 2006, pp. 46-56. doi:10.1016/j.solmat.2005.01.010

[16] Y. Ono, T. Oku, T. Akiyama, Y. Kanamori, Y. Ohnishi, Y. Ohtani and M. Murozono, "Microstructure Analysis of Spherical Silicon Solar Cells Coated with Anti-Reflection Films," Journal of Physics: Conference Series, Vol. 352, 2012, Article ID: 012023. doi:10.1088/1742-6596/352/1/012023

[17] C. K. Huang, H. H. Lin, J. Y. Chen, K. W. Sun and W. L. Chang, "Efficiency Enhancement of the Poly-Silicon Solar Cell Using Self-Assembled Dielectric Nanoparticles," Solar Energy Materials and Solar Cells, Vol. 95, No. 8, 2011, pp. 2540-2544. doi:10.1016/j.solmat.2011.03.006

[18] S. Omae, T. Minemoto, M. Murozono, H. Takakura and Y. Hamakawa, "Crystal Evaluation of Spherical Silicon Produced by Dropping Method and Their Solar Cell Performance," Solar Energy Materials and Solar Cells, Vol. 90, No. 20, 2006, pp. 3614-3623. doi:10.1016/j.solmat.2006.06.056

[19] Z. Liu, K. Asai, A. Masuda, T. Nagai, Y. Akashi, M. Murozono and M. Kondo, "Improvement of the Production Yield of Spherical Si by Optimization of the Seeding Technique in the Dropping Method," Japanese Journal of Applied Physics, Vol. 46, 2007, pp. 5695-5700. doi:10.1143/JJAP.46.5695

[20] W. Liu, C. Jia, C. Jin, L. Yao, W. Cai and X. Li, "Growth Mechanism and Photoluminescence of CdS Nanobelts on Si Substrate," Journal of Crystal Growth, Vol. 269, No. 2-4, 2004, pp. 304-309. doi:10.1016/j.jcrysgro.2004.05.093

[21] T. Minemoto, M. Murozono, Y. Yamaguchi, H. Takakura and Y. Hamakawa, "Novel Deposition Method of AntiReflective Coating for Spherical Silicon Solar Cells," Solar Energy Materials \& Solar Cells, Vol. 90, No. 18-19, 2006, pp. 2995-3000. doi:10.1016/j.solmat.2006.06.005

[22] T. Minemoto, H. Takakura and Y. Hamakawa, "Chemical Bath Deposition for the Fabrication of Antireflective
Coating of Spherical Silicon Solar Cells," Solar Energy Materials and Solar Cells, Vol. 90, No. 20, 2006, pp. 3576-3582. doi:10.1016/j.solmat.2006.06.046

[23] E. Elangovan and K. Ramamurthi, "A Study on Low Cost-High Conducting Fluorine and Antimony-Doped Tin Oxide Thin Films," Applied Surface Science, Vol. 249, No. 1-4, 2005, pp. 183-196. doi:10.1016/j.apsusc.2004.11.074

[24] T. Nagai, Z. Liu, A. Masuda and M. Kondo, "Characterization of Spherical Si by Photoluminescence Measurement," Journal of Applied Physics, Vol. 101, No. 10, 2007, Article ID: 103530. doi:10.1063/1.2736944

[25] S. Omae, T. Minemoto, M. Murozono, H. Takakura and Y. Hamakawa, "Crystal Characterization of Spherical Silicon Solar Cell by X-ray Diffraction," Japanese Journal of Applied Physics, Vol. 45, No. 5A, 2006, pp. 39333937. doi:10.1143/JJAP.45.3933

[26] G. J. McCarthy and J. M. Welton, "X-Ray Diffraction Data for $\mathrm{SnO}_{2}$. An Illustration of the New Powder Data Evaluation Methods," Powder Diffraction, Vol. 4, No. 3, 1989, pp. 156-159. doi:10.1017/S0885715600016638

[27] P. P. Edwards, A. Porch, M. O. Jones, D. V. Morgan and R. M. Perks, "Basic Materials Physics of Transparent Conducting Oxides," Dalton Transactions, Vol. 19, 2004, pp. 2995-3002. doi:10.1039/b408864f

[28] T. Minami, "Transparent Conducting Oxide Semiconductors for Transparent Electrodes," Semiconductor Science and Technology, Vol. 20, No. 4, 2005, pp. S35-S44. doi:10.1088/0268-1242/20/4/004

[29] C. H. Han, S. D. Han, I. Singh and T. Toupance, "MicroBead of Nano-Crystalline F-Doped $\mathrm{SnO}_{2}$ as a Sensitive," Sensors and Actuators B: Chemical, Vol. 109, No. 2, 2005, pp. 264-269. doi:10.1016/j.snb.2004.12.115

[30] V. Kumar, A. Govind and R. Nagarajan, "Optical and Photocatalytic Properties of Heavily F-Doped $\mathrm{SnO}_{2}$ Nanocrystals by a Novel Single-Source Precursor Approach," Inorganic Chemistry, Vol. 50, No. 12, 2011, pp. 56375645. doi:10.1021/ic2003436

[31] B. Zhang, Y. Tian, J. X. Zhang and W. Cai, "The Studies on the Role of Fluorine in $\mathrm{SnO}_{2}: \mathrm{F}$ Films Prepared by Spray Pyrolysis with $\mathrm{SnCl}_{4}$," Journal of Optoelectronics and Advanced Materials, Vol. 13, No. 1, 2011, pp. 89-93. 